\title{
Development of nuclear SNP markers for Mahogany (Swietenia spp.)
}

\author{
Birte Pakull ${ }^{1}$ (D . Lasse Schindler ${ }^{1} \cdot$ Malte Mader $^{1} \cdot$ Birgit Kersten $^{1} \cdot$ Celine Blanc-Jolivet $^{1} \cdot$ Maike Paulini $^{1}$. \\ Maristerra R. Lemes ${ }^{2}$. Sheila E. Ward ${ }^{3}$. Carlos M. Navarro ${ }^{4}$. Stephen Cavers ${ }^{5,8}$ - Alexandre M. Sebbenn ${ }^{6}$. \\ Omar di Dio ${ }^{6} \cdot$ Erwan Guichoux $^{7} \cdot$ Bernd Degen $^{1}$
}

Received: 6 April 2020 / Accepted: 23 July 2020 / Published online: 12 August 2020

(C) The Author(s) 2020

\begin{abstract}
Swietenia species are the most valuable American tropical timbers and have been heavily overexploited for decades. The three species are listed as either vulnerable or endangered by IUCN and are included on Appendix II of CITES, yet illegal exploitation continues. Here, we used restriction associated DNA sequencing to develop a new set of 120 SNP markers for Swietenia sp., suitable for MassARRAY ${ }^{\circledR i P L E X}{ }^{\mathrm{TM}}$ genotyping. These markers can be used for population genetic studies and timber tracking purposes.
\end{abstract}

Keywords SNPs $\cdot$ Mahogany $\cdot$ Swietenia spp. $\cdot$ MassARRAY@iPLEX ${ }^{\mathrm{TM}}$

The genus Swietenia includes the species: Swietenia mahagoni (L.) Jacq. (Small-leaved mahogany, native to Florida and the Caribbean islands), Swietenia macrophylla King. (Big-leaved mahogany, native to Central and South America) and Swietenia humilis Zucc. (Pacific Coast mahogany, native to the relatively dry Central American Pacific coast) (Schütt et al. 2014). While S. mahagoni is no longer traded

Electronic supplementary material The online version of this article (https://doi.org/10.1007/s12686-020-01162-8) contains supplementary material, which is available to authorized users.

Birte Pakull

birte.pakull@thuenen.de

Thünen Institute of Forest Genetics, Sieker Landstrasse 2, 22927 Grosshansdorf, Germany

2 Laboratório de Genética e Biologia Reprodutiva de Plantas, Instituto Nacional de Pesquisas da Amazônia, Av André Araújo 2936, Manaus, AM 69057-375, Brazil

3 Mahogany for the Future Inc., San Juan, PR 00928, USA

4 Universidad Nacional, Calle 9, Avenidas 0 y 9, Heredia, Costa Rica

5 UK Centre for Ecology \& Hydrology, Midlothian, Penicuik, Scotland EH6 0QB, UK

6 Instituto Florestal de São Paulo, CP 1322, São Paulo, SP 01059-970, Brazil

7 University of Bordeaux, INRAE, BIOGECO, 33610 Cestas, France

8 Bush Estate, Midlothian, Penicuik, Scotland EH6 0QB, UK commercially because of past overexploitation, $S$. macrophylla is now the most valuable and economically important American tropical timber (Louppe et al. 2008). Swietenia wood is used for high-class furniture, boat building, musical instruments etc. All three mahogany species are listed on CITES (Convention on International Trade in Endangered Species, Appendix II) and on the IUCN red list, where $S$. macrophylla and S. humilis are listed as vulnerable and $S$. mahagoni is classified as endangered.

Illegal logging is a major threat to the sustainable use of natural forests. Laws like the European Union Timber Regulation and an amendment of the Lacey Act in the US prohibit the trade of illegally sourced timber. However, existing timber-tracking/chain-of-custody systems are based mainly on electronic tags or paper-based documentation, and are vulnerable to falsification. Therefore, efforts to establish genetic methods for timber tracking are being undertaken. Several academic studies documenting population genetic structure in Swietenia species have been completed, based on the analysis of nuclear and chloroplast microsatellite (SSR) markers (e.g. Degen et al. 2013; Lemes et al. 2010; Lemes et al. 2003; Novick et al. 2003). However, genotyping of SSR loci from timber material can be difficult as DNA extracts are often low quality, which impedes the amplification of relatively long SSR-fragments (typically 100-300 bp). Consequently, single nucleotide polymorphism (SNP) markers have become the marker of choice for timber forensics, as they can be characterized in much shorter fragments, are 
simple to standardize among laboratories, and are fast and low-cost to develop in large numbers (Blanc-Jolivet et al. 2017). SNP sets have been developed for timber tracking purposes in other commercially important tropical tree species, e.g., Hymenaea spp. (Chaves et al. 2019), Dipteryx spp. (Honorio Coronado et al. 2019), Cedrela spp. (ParedesVillanueva et al. 2019), Jacaranda copaia (Sebbenn et al. 2019), Carapa spp. (Tysklind et al. 2019), Entandrophragma cylindricum (Blanc-Jolivet et al. 2018), Handroanthus spp. (Meyer-Sand et al. 2018) and Milicia spp. (Blanc-Jolivet et al. 2017).

Here, we describe a new set of 120 SNPs for Swietenia spp., which can be used for population genetic studies and timber tracking purposes.

Tissues (predominantly leaves) from S. macrophylla, S. humilis and S. mahagoni were harvested in Central and South American countries (Brazil, Belize, Bolivia, Costa Rica, El Salvador, Guatemala, Honduras, Mexico, Nicaragua, and Panama). Samples were dried with silica gel. DNA isolation from dried cambium and leaf material was carried out according to Dumolin et al. (1995). DNA isolation from wood material was carried out according to Lowe et al. (2015). SNP discovery was based on restriction-associated DNA sequencing (RADseq, Miller et al. 2007). RADseq was carried out by Floragenex (Portland, USA) using genomic DNA from five individuals of $S$. macrophylla originating from Bolivia, Brazil, Costa Rica, Honduras and Mexico. Libraries were prepared with $S b f \mathrm{I}$ and sequenced using $2 \times 100$ bp paired-end Illumina HiSeq. The Brazilian sample was used for reference assembly. A total of 2450 SNPs (variant call format 4.1) were identified on 1011 reference contigs (stringent mapping conditions). An initial set of 480 SNP markers was compiled based on the results of the RADseq approach. Selection criteria were: strictly no other SNP present within at least $50 \mathrm{bp}$ on both sides of a selected SNP, location on different scaffolds, sufficient sequence coverage and different patterns of allele distribution among the different individuals used for sequencing. The 480 selected SNPs were used for MassARRAY@iPLEX ${ }^{\mathrm{TM}}$ (Agena Biosciences, Hamburg, Germany) genotyping. Alleles were called using Typer Viewer v.4.0.24.71 (Agena Biosciences). The screening included 94 samples (Suppl. 1), representing all three species (S. macrophylla: 69 individuals, S. humilis: 11 individuals, S. mahagoni: 10 individuals), two wood samples and two individuals of the related species Carapa guianensis and Carapa procera. The individuals originated from at least 13 different countries (Brazil, Belize, Bolivia, Costa Rica, Dominican Republic, El Salvador, Guatemala, Honduras, Mexico, Nicaragua, Panama, USA and Venezuela). Some samples-especially $S$. mahagoni-originated from botanical gardens. The two DNA samples extracted from wood were included to test the performance of the markers for timber genotyping. Failed markers with no amplification or contaminated negative control were removed from the dataset, leaving a total of 384 loci for further analysis. Individuals were then grouped according to: (1) species (all individuals) and (2) country of origin (individuals of each species separately). For each grouping we calculated: the percentage of analyzable individuals per marker, the fixation index $\left(\mathrm{F}_{\mathrm{IS}}\right)$ as an indicator of potential null alleles or allele fixation within a group (Nei and Chesser 1983), the effective number of alleles $\left(A_{e}\right)$, the genetic differentiation $(\delta)$ among groups (Gregorius 1987), the correlation between genetic and geographic distance (only when grouped according to country of origin), and population fixation index $\mathrm{F}_{\mathrm{ST}}$ (Nei and Chesser 1983), using GDANT (Degen, unpublished, Suppl. 2). A final marker set of 120 SNPs was determined, prioritizing markers with high rates of amplification, high differentiation power among groups, and-if availablehigh correlation between genetic and geographic distance. The list of the 120 SNP loci included in the final marker set is in Suppl. 3.

Acknowledgements Open Access funding provided by Projekt DEAL. This research was supported by the German Federal Ministry of Food and Agriculture ("Large scale project on genetic timber verification", project No. 28I-001-01). Genotyping was performed at the Genome Transcriptome Facility of Bordeaux Genomic and Sequencing Facility of Bordeaux (grants from Investissements d'Avenir, Convention attributive d'aide EquipEx Xyloforest: ANR-10-EQPX-16-01grants from the Conseil Regional d'Aquitaine no. 20030304002FA and 20040305003FA, the European Union, FEDER no. 2003227 and Investissements d'avenir, no. ANR-10-EQPX-16-01 and CEBA: ANR-10LABX-25-01 to the UMR EcoFoG), with the help of Marie Massot.

Open Access This article is licensed under a Creative Commons Attribution 4.0 International License, which permits use, sharing, adaptation, distribution and reproduction in any medium or format, as long as you give appropriate credit to the original author(s) and the source, provide a link to the Creative Commons licence, and indicate if changes were made. The images or other third party material in this article are included in the article's Creative Commons licence, unless indicated otherwise in a credit line to the material. If material is not included in the article's Creative Commons licence and your intended use is not permitted by statutory regulation or exceeds the permitted use, you will need to obtain permission directly from the copyright holder. To view a copy of this licence, visit http://creativecommons.org/licenses/by/4.0/.

\section{References}

Blanc-Jolivet C, Kersten B, Daïnou K, Hardy O, Guichoux E, Delcamp A, Degen B (2017) Development of nuclear SNP markers for genetic tracking of Iroko, Miliciaexcelsa and Miliciaregia. Conserv Genet Resour 9:531-533. https://doi.org/10.1007/s1268 6-017-0716-2

Blanc-Jolivet C, Kersten B, Bourland N, Guichoux E, Delcamp A, Doucet JL, Degen B (2018) Development of nuclear SNP markers for the timber tracking of the African tree species Sapelli, 
Entandrophragmacylindricum. Conserv Genet Resour 10:539541. https://doi.org/10.1007/s12686-017-0872-4

Chaves CL, Blanc-Jolivet C, Sebbenn AM, Mader M, Meyer-Sand BRV, Paredes-Villanueva K, Honorio Coronado EN, GarciaDavila C, Tysklind N, Troispoux V, Massot M, Degen B (2019) Nuclear and chloroplastic SNP markers for genetic studies of timber origin for Hymenaea trees. Conserv Genet Resour 11:329331. https://doi.org/10.1007/s12686-018-1077-1

Degen B, Ward SE, Lemes MR, Navarro C, Cavers S, Sebbenn AM (2013) Verifying the geographic origin of mahogany (Swieteniamacrophylla King) with DNA-fingerprints. Forensic Sci Int Genet 7:55-62. https://doi.org/10.1016/j.fsigen.2012.06.003

Dumolin S, Demesure B, Petit R (1995) Inheritance of chloroplast and mitochondrial genomes in pedunculate oak investigated with an efficient PCR method. Theor Appl Genet 91:1253-1256

Gregorius HR (1987) The relationship between the concepts of genetic diversity and differentiation. Theor Appl Genet 74:397-401

Honorio Coronado EN, Blanc-Jolivet C, Mader M, Garcia-Davila C, Sebbenn AM, Meyer-Sand BRV, Paredes-Villanueva K, Tysklind N, Troispoux V, Massot M, Degen B (2019) Development of nuclear and plastid SNP markers for genetic studies of Dipteryx tree species in Amazonia. Conserv Genet Resour 11:333-336. https://doi.org/10.1007/s12686-019-01081-3

Lemes MR, Gribel R, Proctor J, Grattapaglia D (2003) Population genetic structure of mahogany (Swietenia macrophylla King, Meliaceae) across the Brazilian Amazon, based on variation at microsatellite loci: implications for conservation. Mol Ecol 12:2875-2883

Lemes MR, Dick CW, Navarro C, Lowe AJ, Cavers S, Gribel R (2010) Chloroplast DNA microsatellites reveal contrasting phylogeographic structure in mahogany (Swieteniamacrophylla King, Meliaceae) from Amazonia and Central America. Trop Plant Biol 3:40-49

Louppe D, Oteng-Amoako A, Brink M, Lemmens R, Oyen L, Cobbinah J (2008) Plant resources of Tropical Africa 7 (1). Timbers. Wageningen, PROTA foundation

Lowe AD, Jardine DI, Cross HB, Degen B, Schindler L, Hoeltken AM (2015) A method of extracting plant nucleic acids from lignified plant tissue. WO 2015/070279 A1

Meyer-Sand BRV, Blanc-Jolivet C, Mder M, Paredes-Villanueva K, Tysklind N, Sebbenn AM, Guichoux E, Degen B (2018)
Development of a set of SNP markers for population genetics studies of Ipe (Handroanthus sp.), a valuable tree genus from Latin America. Conserv Genet Resour 10:779-781. https://doi. org/10.1007/s12686-017-0928-5

Miller MR, Dunham JP, Amores A, Cresko WA, Johnson EA (2007) Rapid and cost-effective polymorphism identification and genotyping using restriction site associated DNA (RAD) markers. Genom Res 17:240-248

Nei M, Chesser RK (1983) Estimation of fixation indices and gene diversities. Ann Hum Genet 47:253-259

Novick RR, Lemes MR, Navarro C, Caccone A, Bermingham E (2003) Genetic structure of Mesoamerican populations of big-leaf mahogany (Swieteniamacrophylla) inferred from microsatellite analysis. Mol Ecol 12:2885-2893

Paredes-Villanueva K, Blanc-Jolivet C, Mader M, Honorio Coronado EN, Garcia-Davila C, Sebbenn AM, Meyer-Sand BRV, Caron H, Tysklind N, Cavers S, Degen B (2019) Nuclear and plastid SNP markers for tracing Cedrela timber in the tropics. Conserv Genet Resour. https://doi.org/10.1007/s12686-019-01110-1

Schütt P, Weisgerber H, Schuck HJ, Stimm B (2014) Bäume der Tropen. Nikol-Verlag, Hamburg

Sebbenn AM, Blanc-Jolivet C, Mader M, Meyer-Sand BRV, ParedesVillanueva K, Honorio Coronado EN, Garcia-Davila C, Tysklind N, Troispoux V, Delcamp A, Degen B (2019) Nuclear and plastidial SNP and INDEL markers for genetic tracking studies of Jacaranda copaia. Conserv Genet Resour 11:341-343. https://doi. org/10.1007/s12686-019-01097-9

Tysklind N, Blanc-Jolivet C, Mader M, Meyer-Sand BRV, ParedesVillanueva K, Honorio Coronado EN, Garcia-Davila C, Sebenn AM, Caron H, Troispoux V, Guichoux E, Degen B (2019) Development of nuclear and plastid SNP and INDEL markers for population genetic studies and timber traceability of Carapa species. Conserv Genet Resour 11:337-339. https://doi.org/10.1007/s1268 6-019-01090-2

Publisher's Note Springer Nature remains neutral with regard to jurisdictional claims in published maps and institutional affiliations. 